\title{
PENGUKURAN PANJANG DAN BOBOT IKAN OSCAR (Amphilophus citrinellus) DI WADUK IR. H. DJUANDA*)
}

\author{
Siti Mariyam ${ }^{1)}$ \\ 1) Teknisi Litkayasa pada Loka Riset Pemacuan Stok Ikan, Jatiluhur-Purwakarta \\ Teregristasi I tanggal: 23 Juli 2008; Diterima setelah perbaikan tanggal: 24 Juli 2008; \\ Disetujui terbit tanggal: 6 Agustus 2008
}

\section{PENDAHULUAN}

Waduk Ir. H. Djuanda, Jatiluhur merupakan suatu badan air yang membendung Sungai Citarum, yang beroperasi sejak tahun 1967 dengan luas maksimal $83 \mathrm{~km}$ dan luas lahan $4.500 \mathrm{~km}$. Fungsi dari Waduk Ir. H. Djuanda, Jatiluhur adalah untuk pembangkit listrik, irigasi wisata, dan sumber penghasilan nelayan dengan cara menangkap ikan. Kedalaman rata-rata 36,4 m dengan kedalaman maksimum 95 m. Berarti waduk ini tergolong perairan yang relatif luas dan cukup dalam (Tjahjo, 1986).

Ikan oskar (Amphilophus citrinellus) merupakan salah satu jenis ikan dominan hasil tangkapan nelayan di Waduk Ir. H. Djuanda, Jatiluhur. Produksi hasil tangkapan dipasarkan dalam bentuk segar dan olahan atau (diasin). Alat yang digunakan jaring dari bahan nilon dengan beberapa ukuran dari mata jaring yaitu 1 sampai dengan 4 inci.

Pengukuran panjang ikan di dalam penelitian biologi perikanan hendak mengikuti suatu ketentuan yang lazim digunakan. Panjang ikan dapat diukur dengan menggunakan sistem metrik atau sistem lain tetapi sistem metrik sangat dianjurkan untuk dipakai karena di Indonesia sudah biasa dan mengenal sistem.

Tujuan pengukuran panjang dan bobot adalah untuk mengetahui kondisi biologi ikan oskar (Amphilophus citrinellus) di perairan Waduk Ir. $\mathrm{H}$. Djuanda, Jatiluhur.

\section{POKOK BAHASAN}

\section{Alat dan Bahan}

Alat pengukur digunakan untuk di lapangan yaitu yang terbuat dari kayu, karena tidak mudah pecah (Gambar 1). Yang perlu diperhatikan dalam pengukuran itu adalah posisi bagian depan ikan bertepatan dengan angka nol. Alat ukur yang digunakan mempunyai ukuran $50 \mathrm{~cm}$.

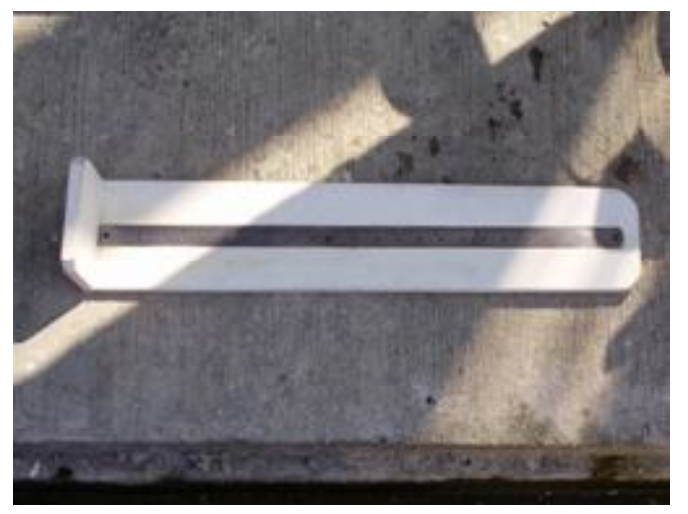

Gambar 1. Alat pengukur ikan yang terbuat dari kayu.

Bahan yang digunakan adalah ikan oskar (Amphilophus citrinellus) hasil tangkapan.

\section{Metode}

Hal-hal yang diperhatikan dalam pengukuran adalah:

1. Kalau ikan sudah kaku jangan lupa meluruskan badan.

2. Jangan lupa merapatkan bibir mulut.

3. Meluruskan bagian ekor.

4. Mengerjakan pengukuran dengan teliti.
5. Pengukuran bobot adalah untuk mengetahui bobot jenis ikan dengan mempergunakan timbangan digital merek AND Made in Korea, dengan ketelitian $5.000 \mathrm{gx} 1 \mathrm{~g}$ (Gambar 2).

Pengukuran panjang dan bobot ikan dilakukan sebagai berikut:

1. Ambil ikan yang sudah tertangkap jaring insang, masukkan ke dalam ember yang sudah disiapkan.

2. Siapkan papan ukur.

3. Hidupkan timbangan yang terlebih dahulu dinolkan. 
4. Letakan ikan di atas papan ukur, ukur panjang total, panjang standar, dan tinggi.

5. Ikan langsung disimpan di atas timbangan yang sudah disiapkan.

6. Catatan hasil pengukuran dan penimbangan.
Keuntungan dari timbangan digital memudahkan pengukuran dan dapat dilakukan secara cepat. Hasil pengukuran dapat terlihat langsung pada layar (display) dan data pengukuran lebih akurat (Effendi, 1975). Pengukuran panjang dan bobot dilakukan (Gambar 3).

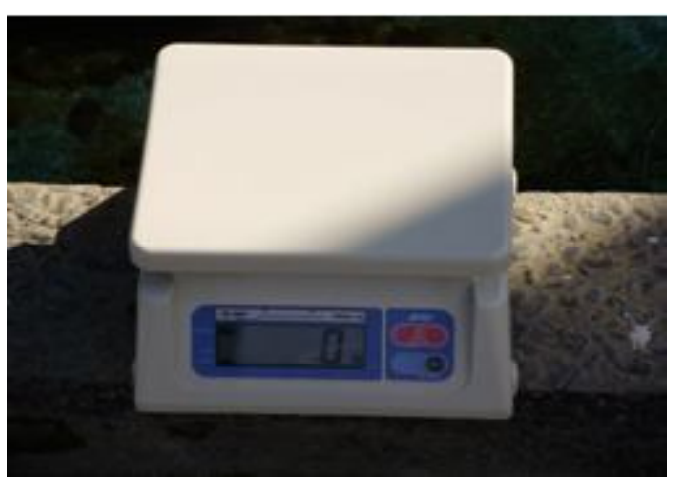

Gambar 2. Alat timbangan untuk mengukur bobot ikan.
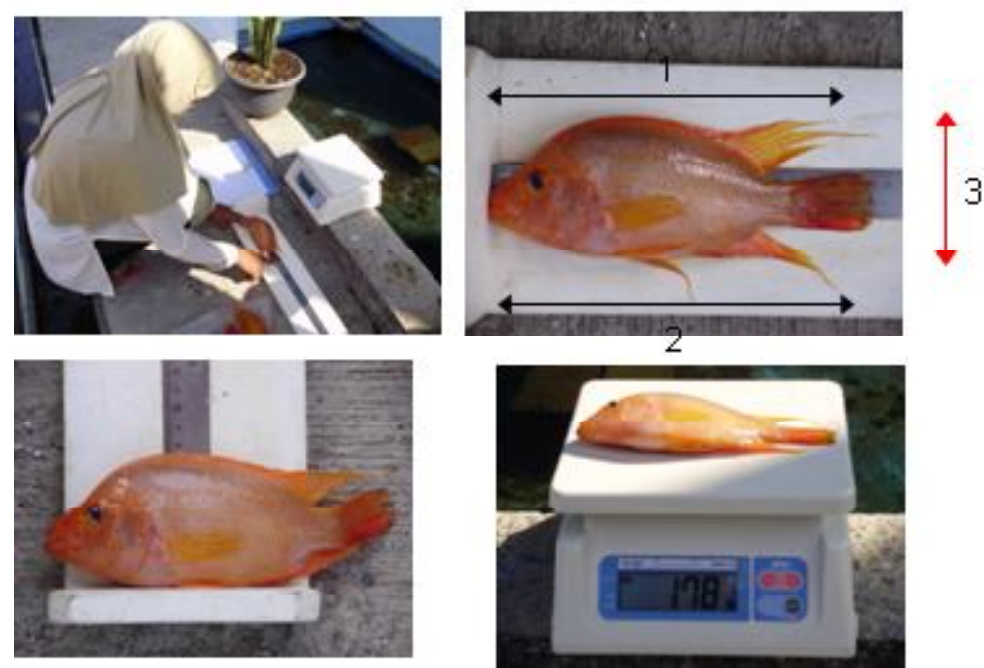

Gambar 3. Cara pengukuran dan penimbangan ikan di lapangan.

\section{HASIL PENGAMATAN}

Hasil pengamatan panjang dan bobot ikan oskar (Amphilophus citrinellus) di daerah dam disajikan pada Tabel 1. Panjang total ikan oskar (Amphilophus citrinellus) di daerah dam pada kisaran 11 sampai dengan $21,5 \mathrm{~cm}$, dengan rata-rata $16,88 \mathrm{~cm}$. Panjang standar 12 sampai dengan $19 \mathrm{~cm}$, dengan rata-rata $14,15 \mathrm{~cm}$. Lebar badan berkisar dari 5 sampai dengan $8,5 \mathrm{~cm}$, dengan rata-rata $6,02 \mathrm{~cm}$. Bobot ikan berkisar dari 30 sampai dengan $230 \mathrm{~g}$, dengan rata-rata 122,93 $\mathrm{cm}$.

Sedangkan hasil pengamatan panjang dan bobot ikan oskar (Amphilophus citrinellus) di daerah
Kerenceng disajikan pada Tabel 2. Panjang total ikan oskar (Amphilophus citrinellus) di daerah dam pada kisaran 11,5 sampai dengan $16,5 \mathrm{~cm}$, dengan ratarata $14,45 \mathrm{~cm}$. Panjang standar 9 sampai dengan 13,5 $\mathrm{cm}$, dengan rata-rata $11,37 \mathrm{~cm}$. Lebar badan berkisar dari 4 sampai dengan $6 \mathrm{~cm}$, dengan rata-rata 5,53 $\mathrm{cm}$. Bobot ikan berkisar dari 30 sampai dengan 110 g, dengan rata-rata $61,25 \mathrm{~cm}$.

Dari hasil pengukuran itu menunjukkan bahwa ukuran panjang dan bobot ikan oskar (Amphilophus citrinellus) di daerah dam lebih tinggi daripada di daerah Kerenceng. 
Tabel 1. Panjang dan bobot ikan oskar (Amphilophus citrinellus) hasil tangkapan di daerah dam, bulan Juni 2007

\begin{tabular}{ccccc}
\hline No. & Panjang total $(\mathbf{c m})$ & Panjang standar $(\mathbf{c m})$ & Lebar badan $\mathbf{( c m})$ & Bobot $\mathbf{( g )}$ \\
\hline 1 & 16,0 & 15,5 & 5,0 & 150 \\
2 & 15,0 & 12,0 & 5,0 & 90 \\
3 & 21,0 & 17,0 & 7,0 & 210 \\
4 & 18,5 & 14,5 & 6,0 & 120 \\
5 & 20,2 & 16,0 & 7,0 & 170 \\
6 & 18,5 & 14,0 & 6,5 & 130 \\
7 & 18,4 & 14,4 & 6,0 & 110 \\
8 & 14,5 & 11,5 & 5,5 & 70 \\
9 & 21,5 & 19,0 & 8,5 & 230 \\
10 & 21,6 & 18,5 & 9,0 & 240 \\
11 & 11,0 & 9,2 & 4,0 & 30 \\
12 & 10,0 & 8,5 & 3,6 & 15 \\
13 & 16,0 & 14,5 & 5,7 & 119 \\
14 & 18,5 & 17,0 & 6,5 & 100 \\
15 & 12,5 & 10,6 & 5,0 & 60 \\
\hline Rata-rata & $\mathbf{1 6 , 8 8}$ & $\mathbf{1 4 , 1 5}$ & $\mathbf{6 , 0 2}$ & $\mathbf{1 2 2 , 9 3}$ \\
\hline
\end{tabular}

Tabel 2. Panjang dan bobot ikan oskar (Amphilophus citrinellus) hasil tangkapan di daerah Kerenceng, bulan Juni 2007

\begin{tabular}{ccccc}
\hline No & Panjang total $(\mathbf{c m})$ & Panjang standar $(\mathbf{c m})$ & Lebar $(\mathbf{c m})$ & Bobot $\mathbf{( g )}$ \\
\hline 1 & 13 & 10 & 5 & 40 \\
2 & 15 & 12 & 6 & 70 \\
3 & 17 & 13,5 & 7 & 110 \\
4 & 14,5 & 11,5 & 6 & 50 \\
5 & 15,5 & 12,0 & 5,5 & 80 \\
6 & 14,5 & 11,5 & 6 & 80 \\
7 & 14,6 & 11 & 5,5 & 60 \\
8 & 15,6 & 12 & 6 & 80 \\
9 & 16,5 & 13 & 7 & 90 \\
10 & 11,5 & 9 & 4,5 & 30 \\
11 & 15,5 & 12 & 6,0 & 60 \\
12 & 11,0 & 9 & 4 & 25 \\
13 & 15,5 & 12,5 & 5,5 & 50 \\
14 & 16,5 & 13 & 6 & 90 \\
15 & 12,5 & 10 & 4,5 & 30 \\
16 & 12,5 & 10 & 4,0 & 35 \\
\hline Rata-rata & $\mathbf{1 4 , 4 5}$ & $\mathbf{1 1 , 3 7}$ & $\mathbf{5 , 5 3}$ & $\mathbf{6 1 , 2 5}$ \\
\hline
\end{tabular}

\section{KESIMPULAN}

Dari hasil pengukuran itu menunjukkan bahwa ukuran panjang dan bobot ikan oskar (Amphilophus citrinellus) di daerah dam lebih tinggi daripada di daerah Kerenceng.

\section{DAFTAR PUSTAKA}

Efendie, M. I. 1975. Metode biologi perikanan. Fakultas Perikanan Institut Pertanian Bogor. Bogor.

Tjahjo, D. W. H.1986. Ciri-ciri morphologi dan potensi pengembangan perikanan Waduk Saguling, Jatiluhur, dan Wonogiri. Buletin Penelitian Perikanan Darat. Vol.5 No.1. Hal. 47-55. 